\title{
Impact of coastal development on mangrove distribution in Cherating Estuary, Pahang, Malaysia
}

\author{
Zuhairi Ahmad*, Muhammad Luqman Mohamad Suharni, Siti Noor Aifa Taib, Muhammad Shaheed \\ Shammodin
}

Department of Marine Science, Kulliyah of Science, International Islamic University Malaysia, Jalan Sultan Ahmad Shah, Bandar Indera Mahkota, 25200, Kuantan, Pahang, Malaysia

* Corresponding author: zuhairiahmad@iium.edu.my

\section{Article history}

Received 1 April 2018

Revised

Accepted XX XXX XXXX

\begin{abstract}
This study examined the impact of various coastal developments on mangrove cover along the Cherating Estuary, Pahang, Malaysia between 1997 and 2016. Series of Landsat imageries at Cherating Estuary have been analyzed using supervised classification. Over $19.99 \%$ (26.275 ha) of mangrove cover was degraded along the Cherating estuary from its total area of 131.642 ha during the past 20 years. The expansion of development or urban area can be observed in 1997 (27.93 ha) and in 2016 (111.02 ha), showing an increase by $297.0 \%$ in 20 years. We identified several causes of mangrove degradation, including mangrove clearing to commercial or residential area, and aquaculture activities. Cherating is one of the main tourism attractions in Pahang. The pace of coastal development throughout the estuary and the coast area had suppressed the mangroves propagation over the years. Long term monitoring of mangrove ecosystems is essential to ensure the survival and sustainability of mangrove associated biodiversity.
\end{abstract}

Keywords: Cherating; remote sensing; GIS; land cover; mangrove.

\section{INTRODUCTION}

Mangrove grows in estuary areas, the intermediate between land and sea, at tropical and sub-tropical climates. It grows within high salinity, destructive winds, strong tides, high temperature and muddy soils (Kathiresan \& Bingham, 2001). It is also defined as a group of shrubs and trees that has a special adaptation to the saline condition of intertidal water, which includes ferns and palms (Spalding, Kainuma, $\&$ Collins, 2010). The mangrove forest of Malaysia covers about 577,500 ha and there are about 60 species of mangroves that available in Malaysia (Jusoff, 2013). The extensive coverage of mangrove forest in Malaysia is due to the humid tropical regions and the geomorphological structure (Juliana et al., 2014).

Coastal development is one of the factors that may cause decline of the mangrove ecosystems. Development has been increasing each year and mangroves have been cleared to give space for these developments. Human settlements, food stalls, schools, aquaculture farm, clinic and health center, parking area, small markets and public prayer rooms are developed. Shahbudin et al. (2012) mentioned that the mangrove forest has its own economic values and coastal development have caused the degradation of mangrove forest. It is reported that the land by the river is low in values and affordable, thus attracting the developer to develop the area and causing severe destruction to mangrove (Dasgupta \& Shaw, 2013).

The current remote sensing technology provides users with multispectral imagery data that is very useful for coastal development mapping with the help of data library from Geographical Information
Systems (GIS), making the mapping process easier and better (Zha et al., 2003). Remote sensing and Geographical Information System (GIS) are the most suitable methods to determine the expansion and degradation of mangrove forests cover, for the land cover changes monitoring in the Cherating river estuary, Pahang. Thus, the impact of the coastal development on mangrove distribution for the past 20 years starting from 1997 to 2016 was investigated based on the mangroves covers and coastal development cover changes for the past 20 years.

\section{LITERATURE REVIEW}

\section{Mangrove forest of Malaysia}

Malaysia mangrove forest lies under the jurisdiction of the various managements at the federal, state and local level. The mangrove forest of Malaysia covers about 577,500 ha with the most extensive mangrove coverage at Sabah with the overall coverage of $59 \%$ of the overall mangrove forest cover of Malaysia and there are about 60 species of mangroves that available in the invaluable mangrove forest of Malaysia (Jusoff, 2013). The extensive coverage of mangrove forest in Malaysia is due to the humid tropical regions and the geomorphological structure (Juliana et al., 2014).

Pahang is one of the largest states in Peninsular Malaysia that has a mangrove forest extension of about 9,000 ha, but only one third of the mangrove forest have been gazetted as Forest Reserve under the jurisdiction of the Department of Forestry (Omar et al., 2016). Mangrove forest in Malaysia is prone to degradation due to the 
mangrove clearance for aquaculture site, shrimp farming, coastal development and settlement (Giri et al., 2008). Thus, monitoring is crucially needed.

\section{Tourism and coastal development}

Malaysia is one of the hotspots for tourism in Southeast Asia Coastal development in Malaysia had been improved in the past 20 years ago, to fulfill the demand for tourism. Mangrove is still a lot in number in South and Southeast Asia, but also the most disturbed ecosystems, distinguished and cleared due to human development and climate change (Dasgupta \& Shaw, 2013). The population of human in Malaysia's cities had been increased from 13,714,897 individuals in 2000 (61.8\% from total population) to $23,622,600$ individuals in 2017 (75.6\% from total population) (DSM, 2015). Major cities in Malaysia are in coastal range such as Kuantan, Kuala Terengganu, Bandar Hilir Melaka, Pulau Pinang, and Kota Bharu. The development and urbanization imply stress on the coastal habitat such as mangrove habitat.

Remote sensing and geographical information system (GIS) in monitoring coastal development and mangrove cover

Monitoring land cover using remotely sensed images is accurate as the remote sensing tools are advancing according to time as urban areas are growing fast (Zha et al., 2003). Since Landsat 8 OLI had been launched in 2013, land cover changes are also being determined using Landsat 8 images. According to Jia et al. (2014), Operating Land Imager (OLI) data has better data quality than ETM+ within visible bands, and has higher performance for land cover classifications. Landsat 8 OLI has 11 spectral bands, including Thermal Infrared Sensor (TIRS) with narrower wavelength covered compared to Landsat 7 ETM+ which has 9 spectral bands with larger wavelength covered (Roy et al., 2014). Higher number of spectral bands will increase accuracy as more classifications can be done based on narrower wavelength covered.

\section{MATERIALS AND METHODS}

\section{Study site}

Cherating is located at the coastal area of Eastern part of Peninsular Malaysia in Pahang state. The area is faced the Southeast China Sea and directly exposed to Southeast Monsoon. It ranges between $04^{\circ} 08^{\prime} 40.3^{\prime \prime}$ to $04^{\circ} 07^{\prime} 32.5^{\prime \prime} \mathrm{N}$ in latitudes and $103^{\circ} 24^{\prime}$ 8.3 " to $103^{\circ} 23^{\prime} 15.7^{\prime \prime} \mathrm{E}$ in longitudes. The climate is equatorial, with uniform air temperature throughout the year, varying from $24^{\circ} \mathrm{C}$ to $28^{\circ} \mathrm{C}$ with an average relative humidity approximately $80 \%$ (DSM, 2015).

\section{METHODOLOGY}

Satellite images of Cherating estuary were obtained from USGS. Five images from previous 20 years at four years interval, were analyzed, which were : $22^{\text {nd }}$ June 1997 from Landsat 4-5 TM; $10^{\text {th }}$ October 2002 on Landsat 7 ETM+ SLC-on (1999-2003); 25 th May 2007 from Landsat 7 ETM+SLC-off (2003 - present); $23^{\text {rd }}$ June 2012 from Landsat 7 ETM+SLC-off $(2003$ - present $)$ and $5^{\text {th }}$ February 2017 from Landsat 8 OLI/TIRS. According to Jia et al. (2014), Operating Land Imager (OLI) data has better data quality than ETM+ within visible bands, and has higher performance for land cover classifications. Landsat 8 OLI has 11 spectral bands, including Thermal Infrared Sensor (TIRS) with narrower wavelength covered compared to Landsat 7 ETM+ which has 9 spectral bands with larger wavelength covered (Roy et al., 2014). Each of five satellite images were pre-processed using ENVI software. Standard atmospheric and geometric correction procedures have been applied to the images. The simplified flowchart was shown in Fig. 2. Total classes of six classes were performed for supervised classifications.

The Kappa coefficient was used on both unsupervised and supervised classifications to compare the error made between classifications generated by the producer and by the users. Each urban area (human settlements, resorts, chalets, school, roads and aquaculture farm) and mangrove cover for every five images were digitized to observe the changes over the past 20 years.

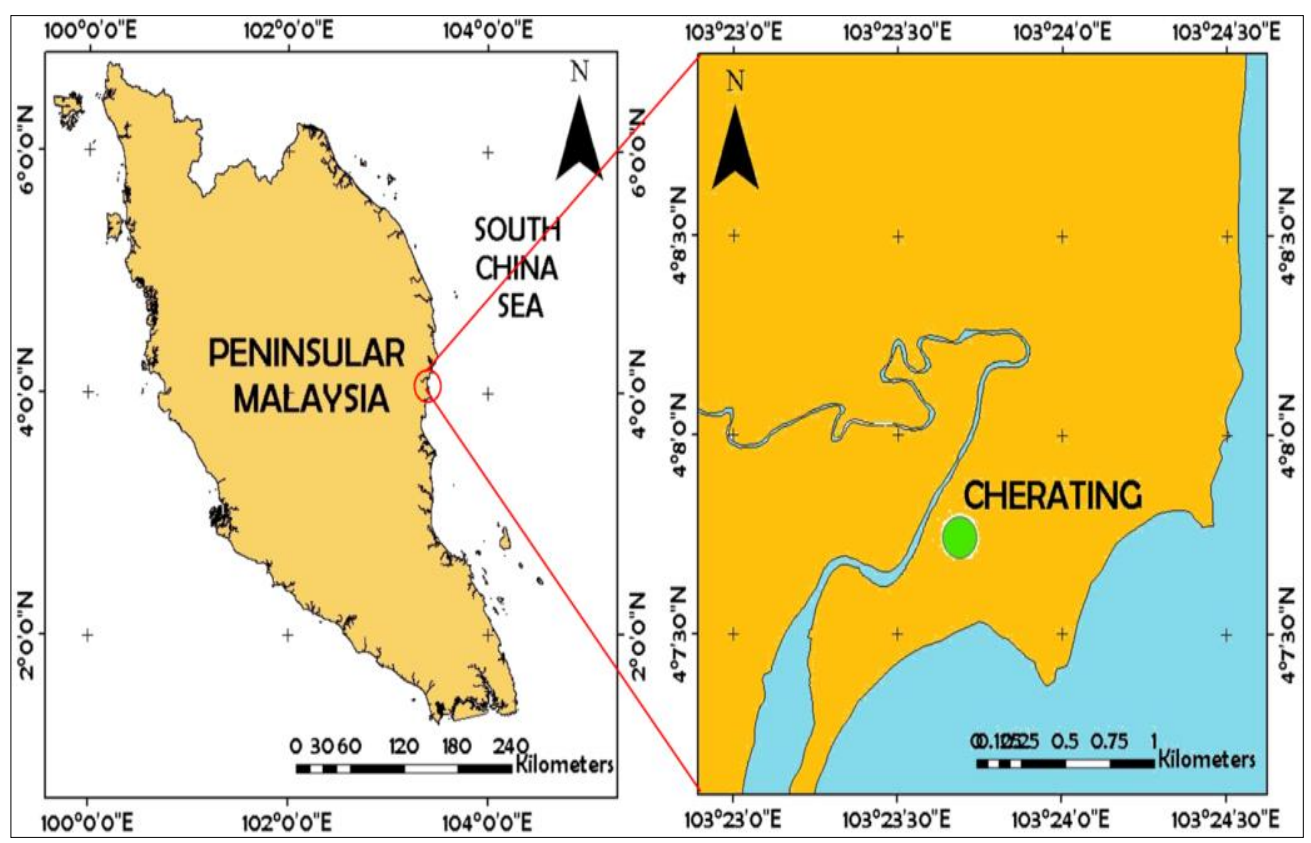

Fig. 1 Study area in Cherating Estuary, Pahang, Malaysia. 


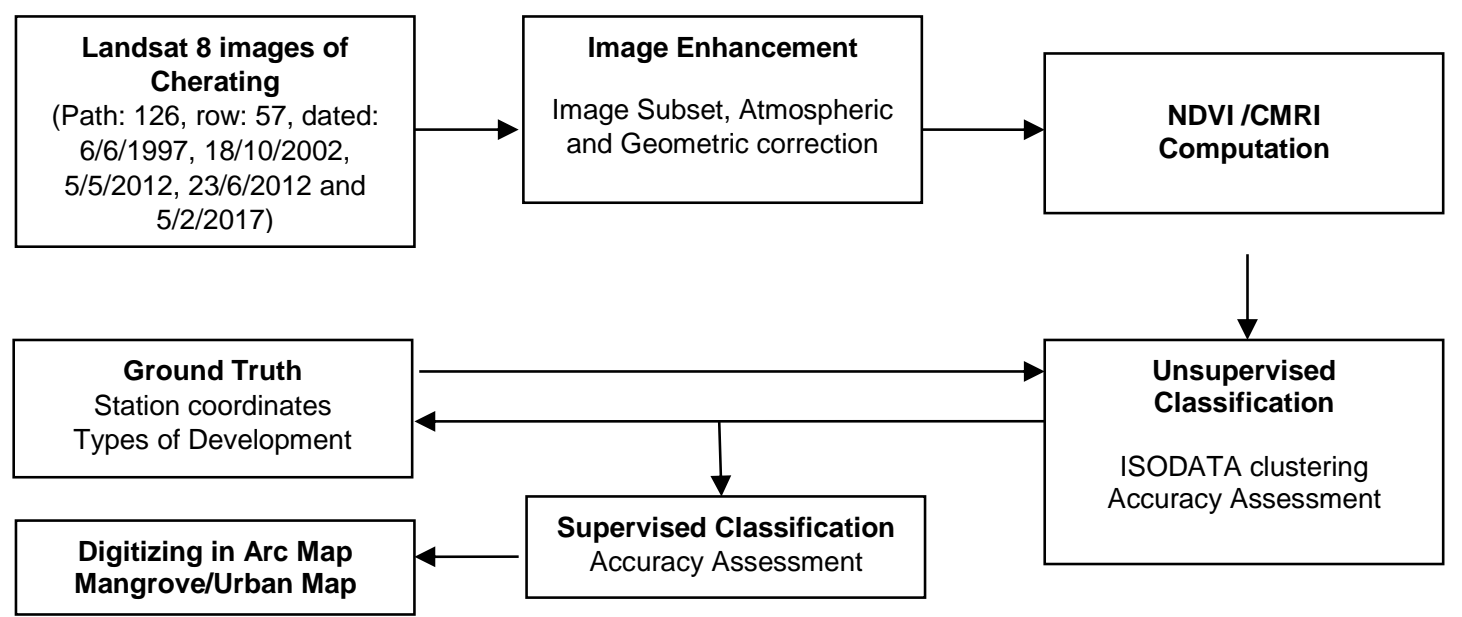

Fig. 2 Flow chart of image processing and mapping.
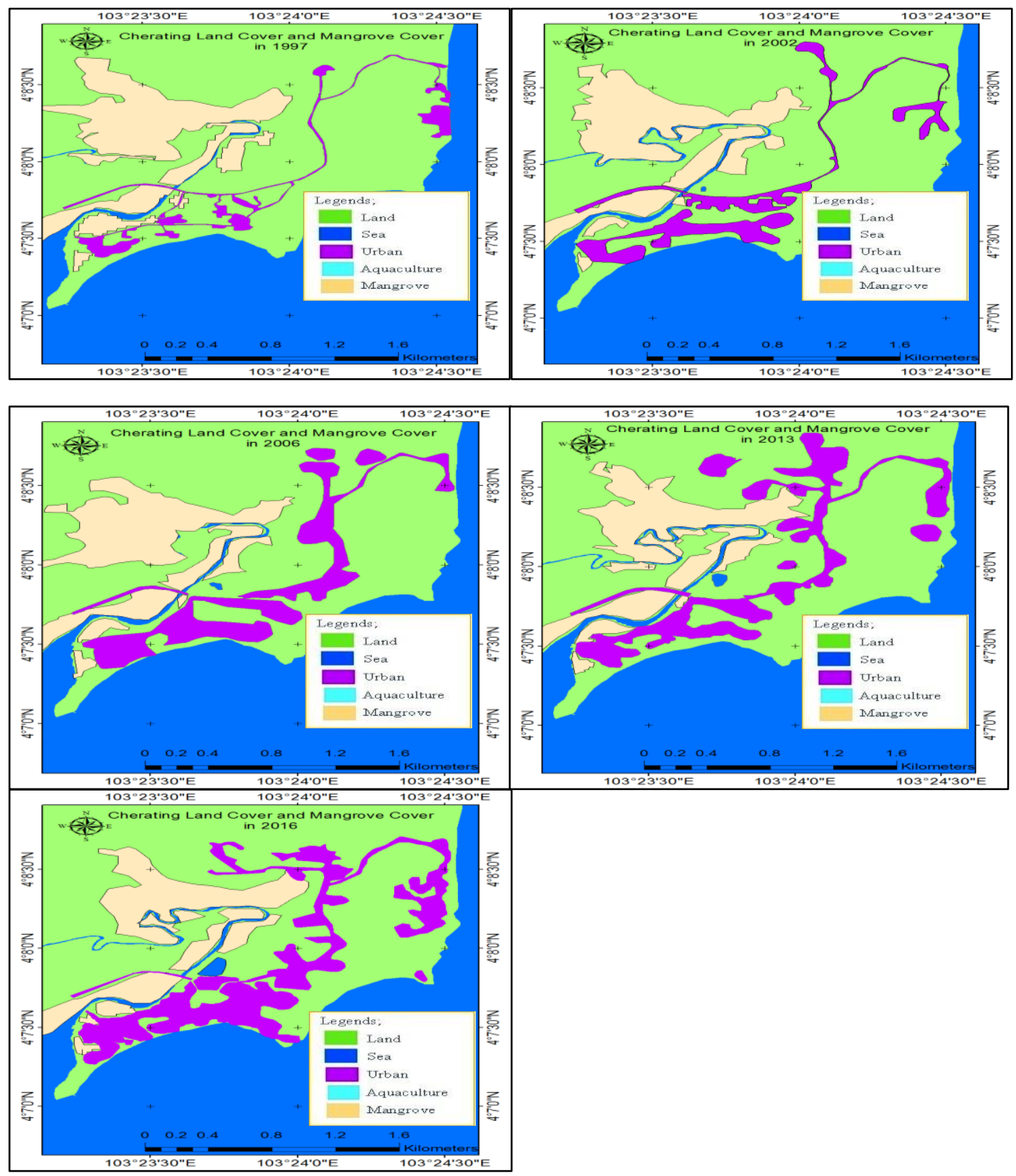

Fig. 3 The maps of mangroves cover changes, coastal development and aquaculture site from the year 1997 to 2016. 
The Mangroves, Urban and Aquaculture site cover changes in Cherating Estuary, Pahang from 1997 to 2016.

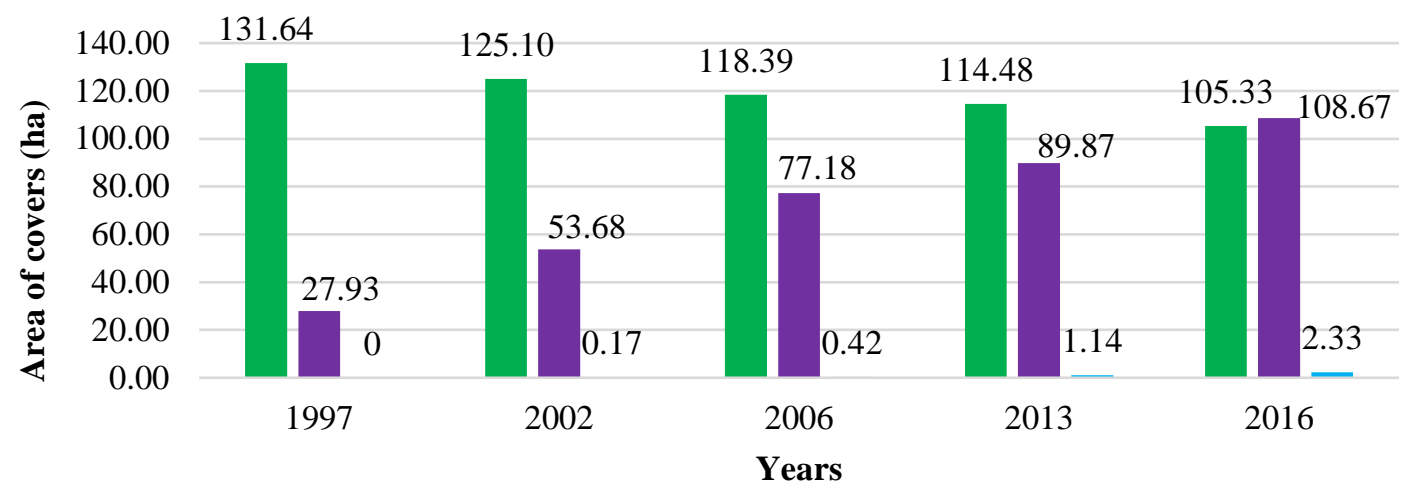

Mangroves cover (ha) $\quad$ Urban cover (ha) $\quad$ Aquaculture/Mariculture cover (ha)

Fig. 4 The chart for the mangroves, urban and aquaculture ponds cover changes from 1997 to 2016 .

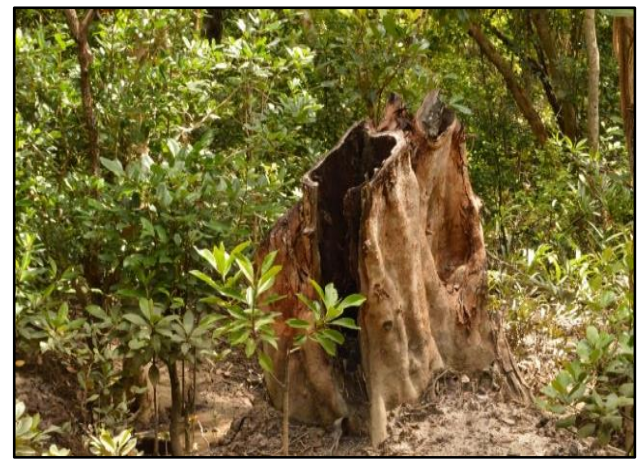

a)

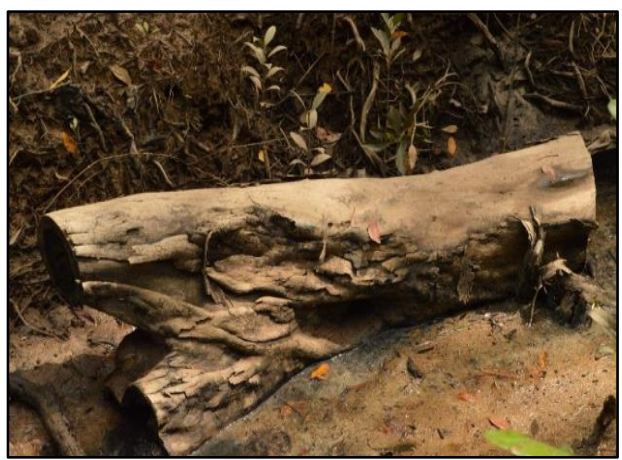

b)

Fig. 5 The images from the field surveys show the remaining mangrove trees after being cut for honey (Kelulut) extraction in Cherating mangrove.

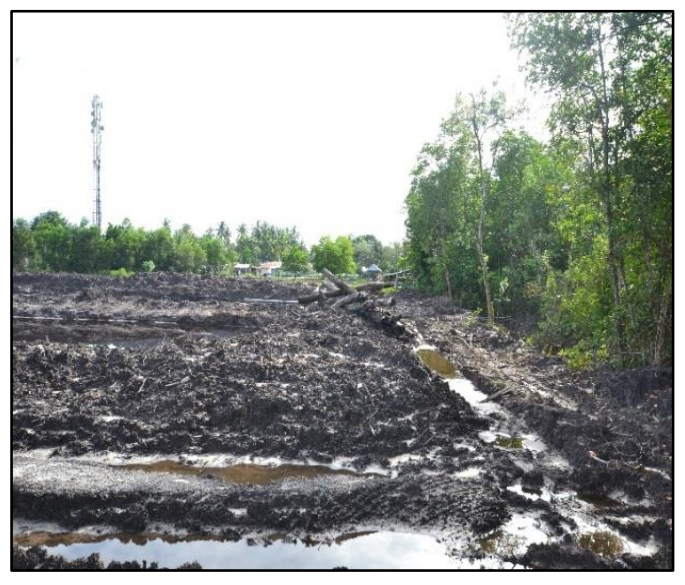

a)

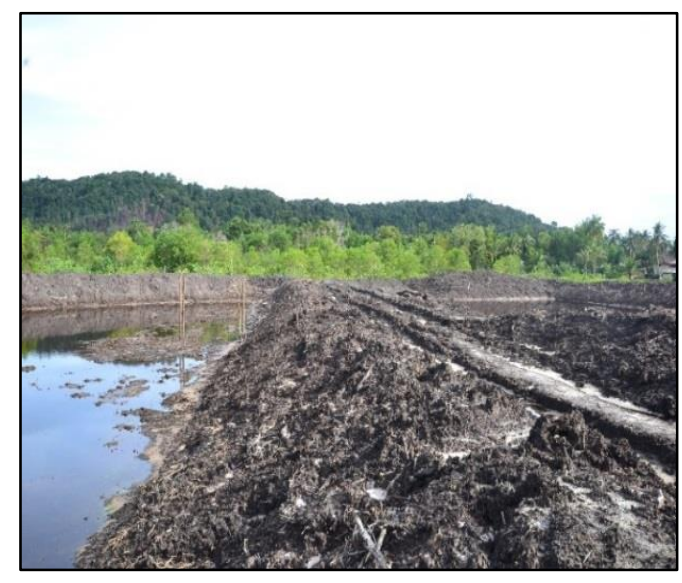

b)

Fig. 6 The mangrove clearing area at Cherating for aquaculture pond extension.

\section{RESULTS AND DISCUSSIONS}

\section{Accuracy assessment}

Based on the combination of supervised and unsupervised analysis, the Kappa coefficient and the percent correctly classified pixels (PCC) in the forms of percentage were obtained for each of the maps generated. The values of the Kappa coefficient and the PCC in the form of confusion matrix are listed in the Table 1. The accuracy assessments are reliable and the Kappa coefficients $(\mathrm{K})$ for supervised classification for images in 1997, 2002, 2013 and 2016 are good. The confusion matrix for supervised classification was ranged from $77 \%$ to $87 \%$. Kappa coefficient for supervised classification was ranged between the value of 0.6 and 0.8. High resolution of Landsat OLI, selection of quality image with less than $10 \%$ cloud cover and 
Table 2 The list of exclusive and non-exclusive mangrove species found in the Cherating estuary, Pahang.

numerous field survey data are the main factors for the reliable classification.

Table 1 The accuracy assessment based on the unsupervised and supervised classification.

\begin{tabular}{|c|c|c|}
\hline Image and Landsat series & $\begin{array}{c}\text { Confusion } \\
\text { matrix }\end{array}$ & $\begin{array}{c}\text { Kappa } \\
\text { coefficient }\end{array}$ \\
\hline 1997 Landsat TM & $77.78 \%$ & 0.6667 \\
\hline 2002 Landsat ETM+ & $84.00 \%$ & 0.7768 \\
\hline 2006 Landsat TM & $87.23 \%$ & 0.8394 \\
\hline 2013 Landsat OLI & $81.32 \%$ & 0.7155 \\
\hline 2016 Landsat OLI & $77.27 \%$ & 0.6405 \\
\hline
\end{tabular}

\section{Expansion/degradation}

Pahang is one of the largest states in Peninsular Malaysia that has a mangrove forest extension of about 9,000 ha, but only one third of the mangrove forest have been gazetted as Forest Reserve under the jurisdiction of the Department of Forestry (Omar et al., 2016). The mangrove cover of the Cherating estuary has been declined due to the development of the agriculture, mariculture/aquaculture ponds, commercial building such as chalets, resorts and hotels and for human settlements. The expansion of the aquaculture/mariculture ponds leads to more mangrove clearing activities at the Cherating estuary. Based on the Fig. 3, the area covered by the coastal development was only 27.93 hectare on the year 1997 and it was increased by $297.0 \%$ in the year 2016. This proved that Cherating had faced rapid development for the past 20 years. The coastal development expansion on 2016 is more rapid than the mangrove covers on 2016.

Details on the total area for urban, mangroves and aquaculture sites in Cherating estuary are shown in Fig. 4. The mangrove at Cherating estuary is not gazetted as Permanent Forest area, thus causing the timbers and the natural products of the area to be easily exploited by the local communities. Timbers also provide the construction material for small jetty in the estuary area for the boating purpose. Some of the mangrove's trees have been cut down in the area for the Meliponula sp. (which known as "Kelulut" in Malay) honey extraction (Fig. 5). As the Meliponula $s p$ lives within the trunks and roots cavities of trees, thus some of the mangroves have been cut down for the honey. The aquaculture site cover was increased from 0 hectare in 1997 to 2.33 hectare in 2016. From the field survey, it was found that more mangroves have been cleared for the extension of the aquaculture farms (Fig. 6). The increasing demands of seafood from the restaurant have increased the demand for the seafood productions. Aquaculture ponds products demand is one of the factors that lead to the expansion of the aquaculture sites.

The mangrove forest in 1997 was reduced from 131.64 ha to 105.33 ha in the past 20 years, a decrease of $20 \%$ in mangrove cover. Anthropogenic activities require mangrove clearing as resources in order to give space for development and transportation. The increase in human population in coastal and estuary areas has increased the need of space to build human settlement, as people prefer coastal area for residential due to high biological productivity (Pourebrahim, Hadipour, \& Bin Mokhtar, 2011). The residential area, urban development and anthropogenic activities lead to mangrove clearing activities and reduce the mangrove cover in Cherating estuary.

\section{Species diversity}

From the field surveys, it was found that there were 15 species of mangroves that comprised of exclusive and non-exclusive mangrove species. There were 9 exclusive and 6 non-exclusive mangrove species found at the Cherating estuary. The lists of mangrove species found are listed in the Table 2.

\begin{tabular}{|c|c|c|}
\hline & Mangrove species found & Classification \\
\hline 1. & Rhizophora apiculata & Exclusive mangrove \\
\hline 2. & Rhizophora mucronata & Exclusive mangrove \\
\hline 3. & Avicennia officinalis & Exclusive mangrove \\
\hline 4. & Xylorcarpus granatum & Exclusive mangrove \\
\hline 5. & Xylorcarpus moluccenis & Exclusive mangrove \\
\hline 6. & Soneratia alba & Exclusive mangrove \\
\hline 7. & Ceriops tagal & Exclusive mangrove \\
\hline 8. & Bruguiera parviflora & Exclusive mangrove \\
\hline 9. & Bruguiera gymnorrhiza & Exclusive mangrove \\
\hline 10. & Hibiscus tiliaceaus & Non-exclusive mangrove \\
\hline 11. & Acrostichum aureum & Non-exclusive mangrove \\
\hline 12. & Acrostichum speciosum & Non-exclusive mangrove \\
\hline 13. & Calamus erinaceus & Non-exclusive mangrove \\
\hline 14. & Nypa fruticans & Non-exclusive mangrove \\
\hline 15. & Pandanus atrocarpus & Non-exclusive mangrove \\
\hline
\end{tabular}

\section{CONCLUSION}

Development and aquaculture ponds reduced the mangrove cover in Cherating estuary. Remote sensing and GIS tools helped monitoring process on mangrove cover and land cover in Cherating for the past 20 years. Public education and awareness campaign must be carried out, especially to the aquaculture farmers about proper culture methods, practices and management, as well as to the developers, on the importance of conserving mangrove habitat and ecosystem. These efforts will help to conserve mangrove habitat and encourage development in a sustainable manner.

\section{ACKNOWLEDGEMENT}

This research was funded by IIUM Research Grant (RIGS 15-1400140).

\section{REFERENCES}

Dasgupta, R., Shaw, R. 2013. Cumulative impacts of human interventions and climate change on mangrove ecosystems of south and southeast asia : An overview. Journal of Ecosystem, vol.2013, 1-15. http://dx.doi.org/10.1155/2013/379429.

DSM. 2015. Department of Statistic Malaysia. Statistic data Warehouse. Retrieved from https://www.dosm.gov.my/v1/.

Giri, C., Zhu, Z., Tieszen, L. L., Singh, A., Gillette, S., Kelmelis, J. A. 2008. Mangrove forest distributions and dynamics (19752005) of the tsunamiaffected region of asia. Journal of Biogeography, 35, 3, 519-528.

Jia, K., Wei, X., Gu, X., Yao, Y., Xie, X., Li, B. 2014. Land cover classification using landsat 8 operational land imager data in beijing, china. Geocarto International, 29, 8, 941-951.

Jusoff, K. 2013. Malaysian mangrove forests and their significance to the coastal marine environment. Polish Journal of Environmental Studies, 22, 4 979-1005.

Kathiresan, K., \& Bingham, B. L.2001. Biology of Mangroves and Mangrove Ecosystems. Advances in Marine Biology, 40, 81-251. https://doi.org/10.1016/S0065-2881(01)40003-4.

Omar, H., Chuah, N. M. J., Parlan, I., Musa, S. 2016. Assessing rate of deforestation and changes of carbon stock on mangroves in pahang, malaysia. Malaysian Forester, 79, 1-2, 174-179. 
Pourebrahim, S., Hadipour, M., Bin Mokhtar, M. 2011. Integration of spatia suitability analysis for land use planning in coastal areas; case of kuala langat district, Selangor, Malaysia. Landscape and Urban Planning, 101, 1, 84-97.

Roy, D. P., Wulder, M. A., Loveland, T. R., C.E, W., Allen, R. G., Anderson, M. C., et al. 2014. Landsat-8: Science and product vision for terrestrial global change research. Remote Sensing of Environment, 145, 154-172.

Shahbudin, S., Zuhairi, A., Kamaruzzaman, B. Y. 2012. Impact of coastal development on mangrove cover in kilim river, langkawi island, malaysia. Journal of Forestry Research, 23, 2, 185-190.
Spalding, M., Kainuma, M., Collins, L. 2010. Book review: World atlas of mangroves. Wetlands, 31, 5, 1003-1005.

Wan Juliana W., Razali M., Latiff A. (2014) Distribution and Rarity of Rhizophoraceae in Peninsular Malaysia. In: Faridah-Hanum I., Latiff A., Hakeem K., Ozturk M. (eds) Mangrove Ecosystems of Asia. Springer, New York, NY.

Zha, Y., Gao, J., Ni, S. 2003. Use of normalized difference built-up index in automatically mapping urban areas from tm imagery. International Journal of Remote Sensing, 24, 3, 583-594. 